International Journal of Sustainable Agricultural Research

2021 Vol. 8, No. 4, pp. 209-221.

$\operatorname{ISSN}(e): 2312-6477$

$\operatorname{ISSN}(p): 2313-0393$

DOI: 10.18488/journal.70.2021.84.209.221

(C) 2021 Conscientia Beam. All Rights Reserved.

check for
updates

\title{
PRODUCTIVITY AND PROFITABILITY OF AROMATIC RICE PRODUCTION IN THE PHILIPPINES
}

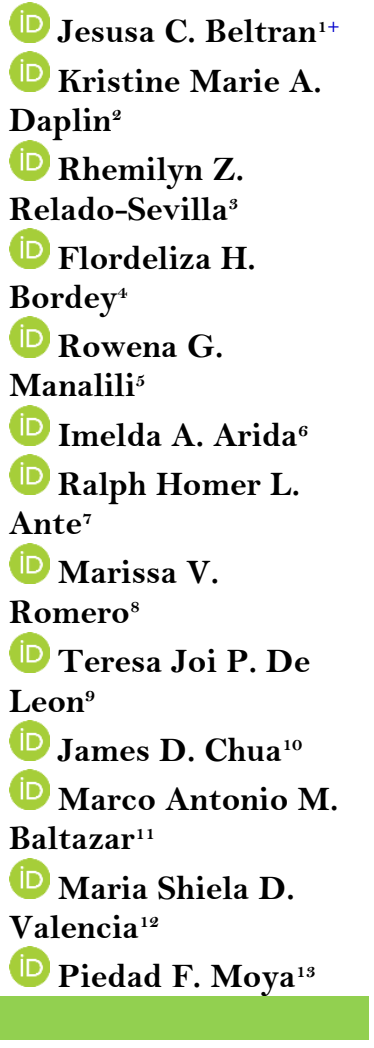

Article History

Received: 12 August 2021 Revised: 6 September 2021 Accepted: 4 October 2021 Published: 26 October 2021

\section{Keywords}

Specialty rice

Pandan-like scent

Pandan-like scent

Grain quality

Import substitution

Supply

Demand.

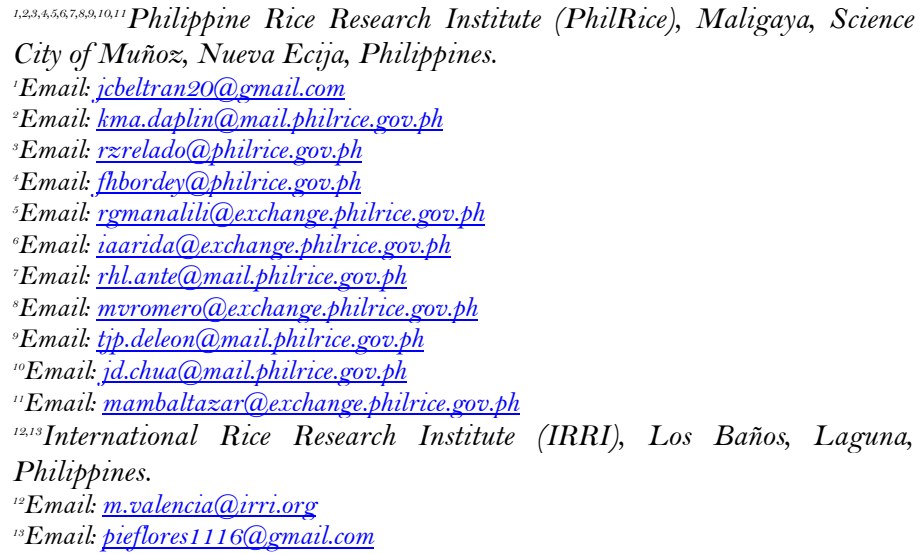

\section{ABSTRACT}

With the 2019 implementation of the Rice Tariffication Law (RTL), prices of ordinary white rice are expected to go down as a response to the influx of cheaper rice imports. This could put the local farmers at a disadvantage and could provoke them to reduce rice cultivation. Production of aromatic rice, a type of specialty rice with pandan-like scent induced by 2-acetyl-1-pyrroline (2AP) compound, could serve as a viable enterprise for the local farmers. Covering the provinces of Oriental Mindoro and Apayao, this study was conducted to produce baseline information and gain a comprehensive understanding of the production and potentials of aromatic rice. A survey was carried out to obtain 2017 cropping season farm-level data from 82 marketoriented farmer-respondents. Descriptive statistics and costs and returns structure were employed for data analysis. Results showed that venturing into aromatic rice cultivation can be a viable enterprise for the farmers as a coping mechanism with the ill effects of RTL. Yield level of modern aromatic rice varieties is at par with the national average. Aromatic rice cultivation also appeared to be profitable. Findings showed that the current local aromatic rice industry has high potential for expansion and opportunity for import substitution. Furthermore, top aromatic rice varieties in the country must be looked into to increase profitability. With these conclusions, strategies for yield enhancement, cost reduction, and premium quality preservation are recommended. 
Contribution/Originality: This study contributes to the existing literature as it cuts across disciplinary approaches to fully understand the Philippine aromatic rice industry. It synthesizes findings into recommended action plans that can help boost the growth of the said industry.

\section{INTRODUCTION}

Specialty rice (SR) types are those varieties that possess unique characteristics making them highly valuable in the market. One of these types is aromatic rice that emits fragrance, particularly a pandan-like scent (Chaudhary, Van Tran, \& Duffy, 2001). Development of fragrance level in these rice varieties is affected by genetic and environmental factors (Prodhan \& Qingyao, 2020). This type contains the main aroma compound 2-acetyl-1pyrroline (2AP) that is responsible for the pandan-like scent (Buttery \& Ling, 1982). This chemical compound is also detected in non-fragrant rice varieties but at a lower concentration level compared to that of aromatic rice (Gaur, Shabir, Pandita, Bharti, \& Malav, 2016; Widjaja, Craske, \& Wootton, 1996). In terms of environmental factors, induction of aroma can be influenced by climate and soil type. Varieties grown in cooler habitats tend to develop higher aroma level (Oad, Oad, Bhand, \& Siddiqui, 2006).

The major categories of aromatic rice are Jasmine type with subtle floral aroma and Basmati type with distinctive spicy fragrance. Jasmine-type rice, originally grown in Thailand as Khao Hom Mali (Vanavichit et al., 2018) is also primarily cultivated in Cambodia (Ponleu \& Sola, 2018) and in Vietnam (Thang, 2017). Indica Jasmine types are found in the Greater Mekong Subregion (Calingacion et al., 2014). Basmati-type rice, on the other hand, is grown in the foothills of the Himalayas (Ashfaq et al., 2015) in India and Pakistan and in other South Asian countries. Sadri types, which are genetically affiliated with Basmati rice of Pakistan and India, are grown in Iran (Calingacion et al., 2014). There are other types of aromatic rice exhibiting 2AP that do not belong to these two major categories; examples are those found in the Philippines. These may be modern or traditional rice varieties (DA (Department of Agriculture), 2015; De Leon, 2012).

Aroma in rice varieties has been considered a favored characteristic by the consumers in choosing what to eat, and by the farmers in selecting what to plant. Thus, aromatic rice is highly regarded as one of the premium rice varieties (Roy, Banerjee, Basak, Kumar, \& Mandal, 2020). Its pandan-like scent translates to a higher price in the market compared to ordinary white rice (Bairagi, Demont, Custodio, \& Ynion, 2020). With this quality attribute, consumer demand for aromatic rice has been generally increasing (Prasad, Padmavathi, \& Suneetha, 2020) and is expected to expand more in the future (Prodhan \& Qingyao, 2020). Rice farmers and traders from different parts of the world are also considering to enter this industry (Giraud, 2008). In fact, aromatic rice has an opportunity to be significant in the export market (United Nations, 1995) since this type is becoming more popular not only across Asia but also in Africa, Europe, and the USA (Ehiakpor, Apumbora, Danso-Abeam, \& Adzawla, 2017).

With these trends in place, the aromatic rice sector has great potential for industry expansion. This potential is important to be explored especially in the current Philippine agriculture setting. As of February 2019, the rice tariffication law (RTL) has been ratified, which means that quantitative restrictions $(\mathrm{QR})$, or the maximum volume quota, has been removed. This has negative impacts on local farmers since cheaper but good-quality imported rice were patronized by market players and consumers. Philippines cannot compete with other neighboring countries due to high costs of production (Beltran et al., 2016).

Opening of trade is double-edged. It opens imports but it also encourages opportunities for exports albeit small and niche markets. The government intends to empower the local farmers through export promotion as part of the eight new paradigms espoused by the Department of Agriculture (DA). The country can harness the opportunity to develop the local aromatic rice industry to take advantage of the growing local and global demand. In view of this, there have been researches in the Philippines characterizing the existing local aromatic rice varieties. Anies, Corpuz, and Romero (2014) studied the grain quality characteristics of traditional upland rice varieties, including aromatic rice. Results showed that unpolished rice samples have slightly fragrant to fragrant attributes. The DA, through 
the Philippine Rural Development Project, released a value chain analysis of aromatic rice in Luzon A Cluster in 2015 (DA (Department of Agriculture), 2015). Dela Cruz, Galindez, and Tapic (2017) then examined the effects of organic farming practices on the yield performance and grain quality of different aromatic rice lines. Mbanjo et al. (2019) on the other hand, researched on genetic diversity of pigmented rice possessing pandan-like scent.

In spite of previous initiatives to profile the aromatic rice being planted in the country, there is still limited knowledge on its productivity and profitability. Studies discussing this SR type are sparse (De Leon, Del Rosario, Arocena, \& Yoshihashi, 2004). Thus, understanding these two factors is vital in presenting aromatic rice's potentials and in crafting strategies to develop the industry. Considering the identified research gap on aromatic rice, this study aims to (1) present farm and farmer profiles; (2) describe the current production system and farming practices; (3) examine the productivity and profitability; (4) identify the best rice varieties; and (5) provide recommendations for harnessing its industry.

\section{METHODOLOGY}

\subsection{Site Selection}

To select provinces producing aromatic rice, site-scanning was conducted through site visits, key informant interviews (KIIs), and focus group discussions (FGDs). Series of consultations with DA-Regional Field Offices (DARFO) and local government units (LGUs) were also done to further validate information. As a result, the provinces of Oriental Mindoro and Apayao were selected as representative sites for the aromatic rice study as there was higher concentration of aromatic rice farmers in these provinces. In particular, the study focused on Calapan City and Naujan town in Oriental Mindoro, and the towns of Conner, Kabugao, and Pudtol in Apayao.

Since Apayao is home to indigenous cultural communities/indigenous peoples (ICC/IP), a free, prior, and informed consent (FPIC) was obtained through the National Commission on Indigenous Peoples (NCIP). All the study processes were done in conformity with the Indigenous Peoples Rights Act of 1997 or Republic Act No. 8371 (Official Gazette of the Republic of the Philippines, 1997). Comprehensive information on the whole application process is available in the book, Philippine Specialty Rice: Understanding Production, Culture, Quality, and Market (Beltran, Romero, Relado-Sevilla, Bordey, \& Moya, 2020).

\subsection{Data and Collection Method}

A farm-level survey targeting market-oriented aromatic rice farmers was conducted. Eighty-two farmers were randomly sampled and interviewed: 42 from Oriental Mindoro and 40 from Apayao. Respondent must be an aromatic rice farmer (either an owner, lessee, tenant, or mortgagee), and must be selling a percentage of his/her produce whether in small portions or in large volumes. The reference harvest periods were in $2017 \mathrm{cropping}$ season. Data collected included farmer and farm profiles, quantity of output, input use, costs, prices, and crop management practices.

\subsection{Analytical Methods}

Overall, descriptive and inferential statistics were undertaken for central tendency measures and test of means. A farm budget structure was also constructed for the production of aromatic rice in the area using actual and imputed prices. Relevant costs included seed, fertilizer, pesticide, irrigation, machine rental, fuel and oil, transportation, labor (land preparation, crop establishment, crop care and maintenance, harvesting and threshing, and postharvest), rental value of land, and interest cost of capital. All costs were expressed on a per-hectare basis. Gross revenue was calculated by multiplying rice yield (after threshing) with the price of wet paddy. Net returns above production cost per hectare were computed using this equation: 


$$
\pi=(y \times p)-\left(\sum_{j} x_{j}\right)
$$

Where $\pi$ is net returns, $y$ is rice yield, $p$ is price of paddy, $x$ 's are the cost items where $j$ is an element of seed, fertilizer, pesticide, labor, irrigation, land, and others. Using the farm budget structure, the costs of rice production and profitability of aromatic rice farming were estimated across provinces.

\subsection{Scope and Limitations}

This study considered certain limitations. The information collected was based on farmer interviews and the accuracy of information was thus affected by the farmers' ability to estimate input use or recall total expenditure in aromatic rice farming for each cropping season. A language barrier also restrained the quality and accuracy of information collected as some of the enumerators are not fluent in the dominant language used in the project sites.

Despite these drawbacks, this baseline project is a stepping stone to fill in the insufficiency on data and research regarding aromatic rice in the country. This dataset remains the most useful and updated source of information for revisiting aromatic rice production. Overall, results from this project will be beneficial to researchers, policymakers, and the farmers themselves.

\section{RESULTS AND DISCUSSION}

\subsection{Farmer and Farm Profile}

Table 1 summarizes the profiles of aromatic rice farmer-respondents from the two provinces. Farmers from Oriental Mindoro were typically 50 years old, male with an average of 9 years of schooling, and have extensive rice farming experience of 24 years. Their households have an average size of four members. Eighty-eight percent of them were affiliated to at least one rice-based organization, majority to farmer associations. Many of them have accessed rice-related trainings since $2014(74 \%)$. They were also generally financially capable, with only $17 \%$ of them borrowing capital. On average, rice farming provided $72 \%$ to the farmers' total household income.

Aromatic rice farmers in Apayao were generally 48 years old, female-dominant, have at least attended up to third year high school, and have been into rice farming for 24 years. Farm households in the area usually have six members. Notably, 90\% of the farmer-respondents belong to an IP group. Majority of these identify themselves as Isneg. More than half of the respondents were members of rice-based organizations and have attended at least one rice-related training since 2014 . However, it can be noted that there was a substantial percentage of those who were not participative in the said type of organization (41\%) and training (44\%). Seventy-five percent of the Apayao aromatic rice farmers relied on borrowings for their farm capital. Lastly, more than half of their total household income resulted from rice farming earnings.

Table-1. Sociodemographic profile of aromatic rice farmers in Oriental Mindoro and Apayao, 2017.

\begin{tabular}{l|c|c}
\hline Farmer characteristic & Oriental Mindoro & Apayao \\
\hline & $\mathrm{n}=42$ & $\mathrm{n}=40$ \\
\hline Age (years) & 50 & 48 \\
\hline Sex (\% male) & 69 & 35 \\
\hline Education (years) & 9 & 9 \\
\hline Farming experience (years) & 24 & 24 \\
\hline Household size (no.) & 4 & 6 \\
\hline IP membership (\% member) & - & 90 \\
\hline Organization (\% member) & 78 & 59 \\
\hline Training (\% trained) & 17 & 75 \\
\hline Capital source (\% borrower) & 72 & 58 \\
\hline Rice income share (\%) & 74 & 56 \\
\hline
\end{tabular}


Characteristics of aromatic rice farms in both provinces are shown in Table 2. Average rice area of farmerrespondents in Oriental Mindoro was 2.58 ha, of which 96\% was devoted to aromatic rice. These farms were owned by $36 \%$ of the farmer-respondents. Majority were irrigated, enabling farmers to plant rice twice a year. Distances from these farms to the nearest main road and market averaged at $0.3 \mathrm{~km}$ and $8 \mathrm{~km}$, respectively.

Rice farm areas in Apayao were owned by 35\% of the farmer-respondents and had an average size of 1.40 ha. Similar with the other site, aromatic rice cultivation took up majority of rice farm areas at $92 \%$. These farms were 2 $\mathrm{km}$ and $10 \mathrm{~km}$ away from the nearest main road and market, respectively. Aromatic rice was generally cultivated in the upland ecosystem (78\%), with rainwater as the major source of irrigation (85\%). These farms are normally situated in middle-to-upper elevations and are along the slopes of forests. With these environmental conditions, rice planting is usually practiced only once a year, with a subsequent fallow period or corn production.

Table-2. Profile of aromatic rice farms, 2017.

\begin{tabular}{|c|c|c|}
\hline \multirow{2}{*}{ Farm characteristic } & Oriental Mindoro & Apayao \\
\hline & $\mathrm{n}=42$ & $\mathrm{n}=40$ \\
\hline Average total rice area (ha) & 2.58 & 1.4 \\
\hline Average total aromatic rice area (ha) & 2.43 & 1.3 \\
\hline Percentage of total aromatic rice area to total rice area & 96 & 92 \\
\hline Tenurial status (\% owned) & 36 & 35 \\
\hline \multicolumn{3}{|l|}{ Source of irrigation (\%) } \\
\hline NIS/CIS & 38 & 3 \\
\hline SSIS (STW, open/dug well, deepwell, SWIP, SFR) & 45 & 3 \\
\hline Rain & 10 & 85 \\
\hline Natural (rivers, streams, free-flowing) & 7 & 10 \\
\hline \multicolumn{3}{|l|}{ Ecosystem (\%)) } \\
\hline Upland & - & 78 \\
\hline Rainfed & 10 & 8 \\
\hline Irrigated & 90 & 15 \\
\hline Distance to road $(\mathrm{km})$ & 0.3 & 2 \\
\hline Distance to market $(\mathrm{km})$ & 8 & 10 \\
\hline
\end{tabular}

\subsection{Yield, Paddy Price, and Gross Revenue}

Figure 1 shows the average and variability of farm yields of aromatic rice in the two provinces. In Oriental Mindoro, yield was estimated at $4.75 \mathrm{t} \mathrm{ha}^{-1}$ with dry equivalent (14\% MC) of $4.42 \mathrm{t} \mathrm{ha} \mathrm{h}^{-1}$. This is considered high since cultivation uses modern varieties and is irrigated. Yields varied widely with the lowest observed at $2.40 \mathrm{tha} \mathrm{h}^{-1}$ and highest at $6.70 \mathrm{t} \mathrm{ha}^{-1}$. This variation may be due to problems such as high incidence of insects (e.g., brown planthoppers and stem borers), diseases, and weeds. Fresh paddy was sold at P16 to P22 $\mathrm{kg}^{-1}$ with an average of P19 $\mathrm{kg}^{-1}$. With these yields and prices, farmers were able to earn an average gross revenue of P92,397 ha-1.

Aromatic rice production in Apayao is chiefly described as subsistence farming. It averaged $2.02 \mathrm{t} \mathrm{ha}{ }^{-1}$ with $^{1.85}$ $t$ ha $^{-1}$ dry equivalent. The lower yield may be attributed to the upland ecosystem, common use of traditional varieties, pest problems, and low fertilizer use. Fresh paddy price of this SR type was comparable to that of existing ordinary white varieties in the area $\left(\mathrm{P} 18 \mathrm{~kg}^{-1}\right)$ in spite of the unique aroma. Low input-output situation of aromatic rice production in Apayao pulled down the average gross revenue at P37,234 ha-1.

\subsection{Input Use and Management Practices \\ 3.3.1. Seeds and Varieties}

NSIC Rc 218 and Dinorado are the two aromatic rice varieties dominantly cultivated in Oriental Mindoro. The former is commonly planted in Region 4B (where the province belongs), along with PSB Rc 19, NSIC Rc 354, and NSIC Rc 394 (PhilRice (Philippine Rice Research Institute), 2018). Despite being susceptible to pests and diseases such as blight, tungro, bacterial leaf blight, brown plant hopper, green leaf hopper, and white stem borer, this 
variety remains a popular choice of the farmers due to its high market price and increasing consumer demand. Note that many farmers in Oriental Mindoro call their rice as Dinorado when it is actually NSIC Rc 218 . With this, it is possible that those who reported Dinorado, or at least a percentage of them, really planted NSIC Rc 218.

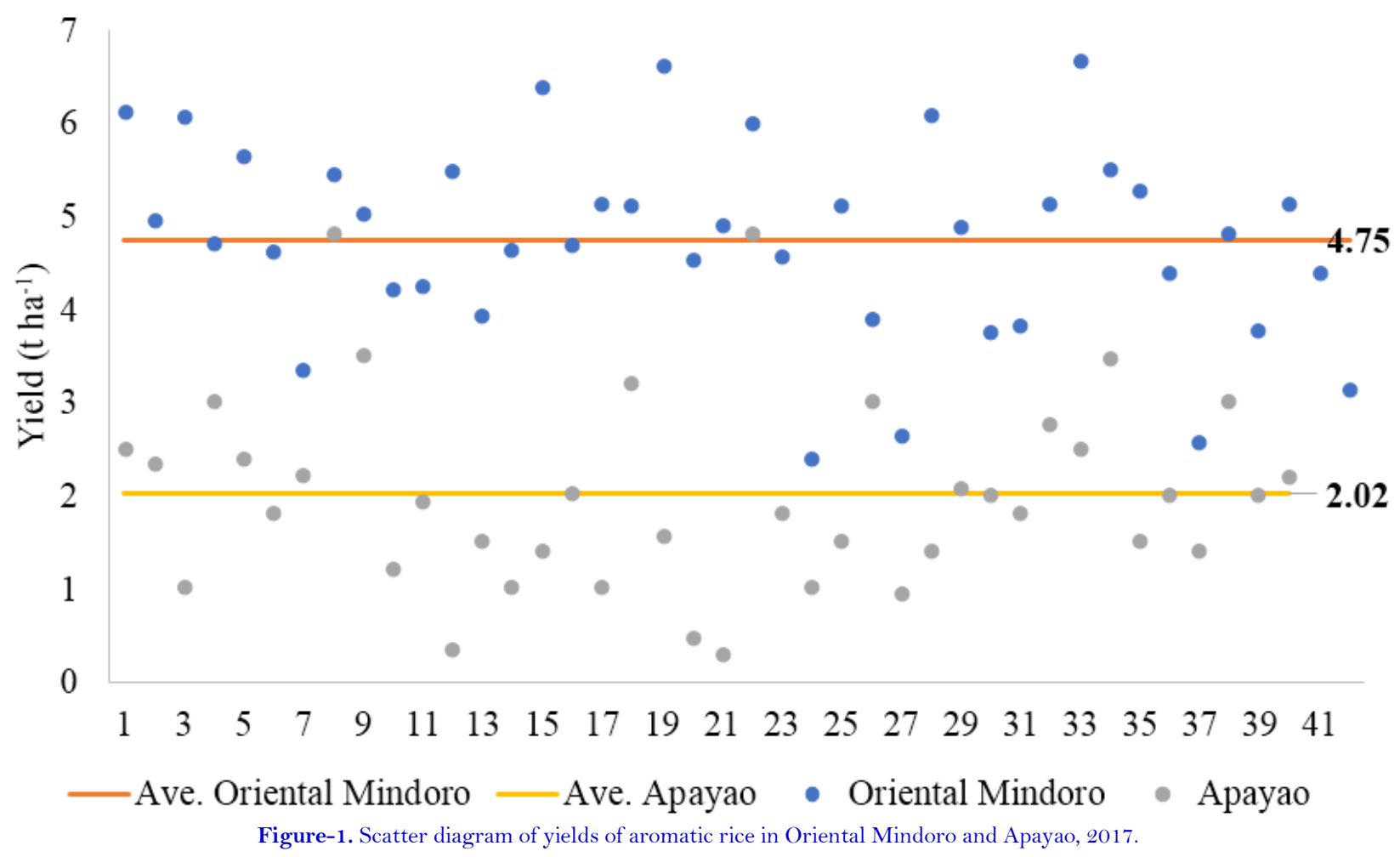

Commonly planted aromatic rice varieties in Oriental Mindoro are certified seeds, which were sourced from seed growers and seed centers, and farmers' saved seeds. Seeding rate was $112 \mathrm{~kg} \mathrm{ha}^{-1}$ (Table 3), which is much higher than the recommended rates for transplanting or direct seeding ordinary white rice varieties. This is to anticipate seedlings damaged by birds, rodents, and other pests. The seeds were commonly direct-seeded through manual broadcasting on wet fields. The system followed a straight-row planting method allotting three seeds per hole.

In Apayao, traditional rice varieties with long maturity periods were preferred: Gobyerno, also known as Bayu, and Palawan topped their list. Farmers typically set aside a portion of their harvests to be used as planting materials for the next cropping season. The average seeding rate was $57 \mathrm{~kg} \mathrm{ha}^{-1}$, which was relatively low. Due to steep slopes of rice farming areas in Apayao, dibbling is most commonly practiced as crop establishment method. Farmers used a wooden stick to create holes which were $26 \mathrm{~cm}$ apart. Each hole contained five to six seeds.

\subsubsection{Fertilizer Use}

Table 3 also presents the average NPK rates applied by aromatic rice farmers in both provinces. On average, farmers in Oriental Mindoro used $92 \mathrm{~kg} \mathrm{~N} \mathrm{ha}{ }^{-1}, 10 \mathrm{~kg} \mathrm{P} \mathrm{ha-1}$, and $32 \mathrm{~kg} \mathrm{~K} \mathrm{ha-1}$ applied three times within a cropping season. For direct-seeded rice, fertilizers were applied 18 days after seeding (DAS), 33 DAS, and 48 DAS. For transplanted rice, applications were carried out 8 days after transplanting (DAT), 25 DAT, and 41 DAT. Farmers commonly applied the following fertilizer grades: complete (14-14-14), urea (46-0-0), ammonium chloride (25-0-0), and potassium nitrate (17-0-17).

Aromatic rice production in Apayao usually required a low $21 \mathrm{~kg} \mathrm{~N}, 1 \mathrm{~kg} \mathrm{P}$, and $1 \mathrm{~kg} \mathrm{~K}$ fertilizers per hectare, as fertilizer application is not a dominant practice in the area. A substantial $43 \%$ of farmers did not apply fertilizers. One reason for this is the steep topography of farm areas, which could lead to soil erosion and fertilizer wastage. 
The farmers also believed that upland areas have more fertile soil. Some $28 \%$ of those who used fertilizers, applied once while $8 \%$ did it twice. First application was usually done at 30 DAS; second dose at 45 DAS. The top three commonly used fertilizers were urea, complete, and ammonium phosphate.

Table-3. Input use in aromatic rice production, 2017.

\begin{tabular}{l|c|c}
\hline \multirow{2}{*}{ Item } & Oriental Mindoro & Apayao \\
\cline { 2 - 3 } & $\mathbf{n = 4 2}$ & $\mathbf{n = 4 0}$ \\
\hline Seed $\left(\mathrm{kg} \mathrm{ha}^{-1}\right)$ & 112 & 57 \\
\hline Fertilizer $\left(\mathrm{kg} \mathrm{ha}^{-1}\right)$ & & 21 \\
\hline $\mathrm{N}$ & 92 & 1 \\
\hline $\mathrm{P}$ & 10 & 1 \\
\hline $\mathrm{K}$ & 32 & \\
\hline Pesticide (kg ai ha-1) & & 0.05 \\
\hline Herbicide & 0.40 & 0.03 \\
\hline Insecticide & 1.41 & \\
\hline Fungicide & 0.13 & \\
\hline Molluscicide & 0.65 & 54.93 \\
\hline Rodenticide & 0.08 & \\
\hline Total labor (md ha-1) & 34.78 & 3.75 \\
\hline Hired labor & & 7.9 \\
\hline Land preparation & 4.38 & 1.37 \\
\hline Crop establishment & 6.17 & 11.68 \\
\hline Crop care and maintenance & 3.17 & 1.09 \\
\hline Harvesting and threshing & 1.29 & \\
\hline Postharvest labor & 1.63 & 7.89 \\
\hline OFE labor & & 5.58 \\
\hline Land preparation & 5.48 & 4.43 \\
\hline Crop establishment & 2.54 & 3.03 \\
\hline Crop care and maintenance & 9.79 & \\
\hline Harvesting and threshing & & 0.33 \\
\hline Postharvest & & \\
\hline
\end{tabular}

\subsubsection{Pesticide Use}

Table 3 describes the pesticide application of aromatic rice farmers in both provinces in terms of active ingredient (ai). Oriental Mindoro farmers widely use pesticides for pest and disease management. Herbicide was applied by $98 \%$ of the farmers against weeds as a consequence of their dominant practice of direct seeding. Average amount used was $0.41 \mathrm{~kg}$ ai ha ${ }^{-1}$, usually applied at 6 and 21 DAS.

Insecticides and molluscicides were sprayed by 95\% of the farmers. Applied at 29 and 49 DAS, much insecticide was reported $(1.41 \mathrm{~kg}$ ai ha-1) due to heavy infestation rice bugs and stem borers. Molluscicide was applied at 3 and 6 DAS at a mean rate of $0.65 \mathrm{~kg}$ ai ha-1. Least used were rodenticides and fungicides. Some $60 \%$ of the farmers used a mean rate of $0.08 \mathrm{~kg}$ ai ha-1 against rodents; $48 \%$ used fungicides at an average amount of $0.13 \mathrm{~kg}$ ai ha-1.

The same cannot be said of the Apayao farmers, only $68 \%$ of whom applied herbicides at a low average rate of $0.05 \mathrm{~kg}$ ai ha-1. Application was 12 days before seeding (DBS) or 27 days after seeding (DAS). Other types of pesticides were rarely used even if a few occurrences of infestation were observed. It is not their common practice to adopt mitigating techniques against pests and diseases.

\subsubsection{Labor Use and Mechanization}

Table 3 summarizes the total labor use whereby Oriental Mindoro farmers spent a total of only 35 man-days (md) to carry out all major activities in a 1-ha farm. This low labor use compared with the national level of $64 \mathrm{md}$ ha $^{-1}$ (PhilRice (Philippine Rice Research Institute), 2012) is mainly because of the dominant practice of direct seeding and adoption of the combine harvester. More than half (52\%) of the activities were done by operator, family, 
and exchange (OFE) labor. The rest, which were performed by hired laborers, were paid using the prevailing wage rate of $\mathrm{P} 300 \mathrm{day}^{-1}$.

Among all farm activities, crop care and maintenance incurred the highest labor use averaging at $13 \mathrm{md} \mathrm{ha}^{-1}$. This was mostly done by family labor. Requiring $10 \mathrm{md} \mathrm{ha}^{-1}$, land preparation activities suited the lowland ecosystem, thus, had labor-intensive practices such as plowing, harrowing, leveling, and even rototilling in some areas. Farmers commonly used hand tractors (95\%), draft animals (88\%), and four-wheel tractors (64\%). The operators were paid either through a daily wage rate or on a per-hectare contract basis. The least laborious activities were harvesting and postharvest, thanks to the use of combine harvester that required an average of 2 md $\mathrm{ha}^{-1}$. In postharvest, only hauling of paddy from the harvesting area to the first point of destination was involved.

Aromatic rice production in Apayao was more labor-intensive since majority of the farm activities were manually done by family labor (53\%). Prevailing wage rates ranged from P200 to P300 per day. Average requirement totaled to $55 \mathrm{md} \mathrm{ha}^{-1}$ even without seedling care and maintenance activities, with harvesting and threshing requiring the largest average of $20 \mathrm{md} \mathrm{ha}^{-1}$. Farmers cannot use combine harvesters in their upland and sloping farmlands. Instead, they used rakem in harvesting rice per panicle.

Another strenuous activity in Apayao was land preparation, which required an average of $12 \mathrm{md} \mathrm{ha}^{-1}$. Adapted to the upland ecosystem, kaingin system was commonly practiced by the farmers instead of the conventional lowland preparation activities. This system usually lasts for 1 to 3 months starting by April, depending on the dryness of the area. It begins with the clearing of woods and grasses surrounding the chosen area bordered with a fire line. This line sets a 3-meter distance from the kaingin area to the rest of the forest to prevent wildfires. Farmers then wait for at least a week with no rainfall before they start burning. They use bamboo to start fire that follows the wind direction. After putting out the fire, they clean the area before cultivating.

Less labor was used for crop care and maintenance since fertilizers and pesticides were rarely applied, with $20 \%$ of the farmer-respondents reporting no pest infestation during the cropping period. Herbicide was only occasionally applied. Some farmers set up scarecrows that made birds shy away from the field. Postharvest was the least laborious as it only involved hauling of the bundled panicles.

\subsection{Cost and Profitability}

Farmers in Oriental Mindoro invested a seasonal average of P63,000 ha-1 or about P13 $\mathrm{kg}^{-1}$ to produce aromatic rice, the biggest chunk of which was incurred by land rent at 30\% (Figure 2). The high cost of land can be attributed to rapid urbanization and land conversion in the area. As discussed earlier, less than half of the farmers owned their farms. Majority rented either as lessee or tenant. Hired labor ate up $24 \%$ of the total cost owing to expensive contract payment $\left(\mathrm{P}_{2}, 500\right.$ to $\left.\mathrm{P} 5,000 \mathrm{ha}^{-1}\right)$ for land preparation, crop establishment, and combine harvesting. Fertilizers and pesticides contributed $13 \%$ and $7 \%$ shares, respectively. Considering all farm production costs, farmers earned an average net income of P29,495 ha-1 (Table 4). Returning the value of imputed costs (i.e., OFE labor, interest on capital, and imputed land rent cost), farmers pocketed a higher return at $\mathrm{P} 48,224 \mathrm{ha}^{-1}$.

In Apayao, farmers spent an average of $\mathrm{P} 13$ on a per-kilogram equivalent or a total expenditure of $\mathrm{P}_{25,211}$ ha $^{-1}$ (Table 4). From the total costs, hired and OFE labors incurred the biggest shares of $30 \%$ and $26 \%$, respectively (Figure 2), resulting from the low level of adoption of machines. Despite scanty applications of chemicals in the farm, farmers allocated a substantial cost of $7 \%$ on pesticides and $5 \%$ on fertilizers. Deducting these expenses from the gross returns, a farmer can attain a net income of $\mathrm{P} 10,934 \mathrm{ha}^{-1}$. Those who own land and capital, and render no OFE labor services may earn P19,566 ha-1.

To boost the profitability of aromatic rice, considerations in grain quality should also be looked into. Romero et al. (2020) subjected paddy and milled aromatic rice samples to grain quality evaluation through sensory and laboratory analysis. Based on cooked rice quality attributes, the best are Gobyerno and Azucena from Apayao, and 
NSIC Rc 218 from Oriental Mindoro. Among the samples, they exhibited the more evident pandan-like scent, best taste, and softest texture.

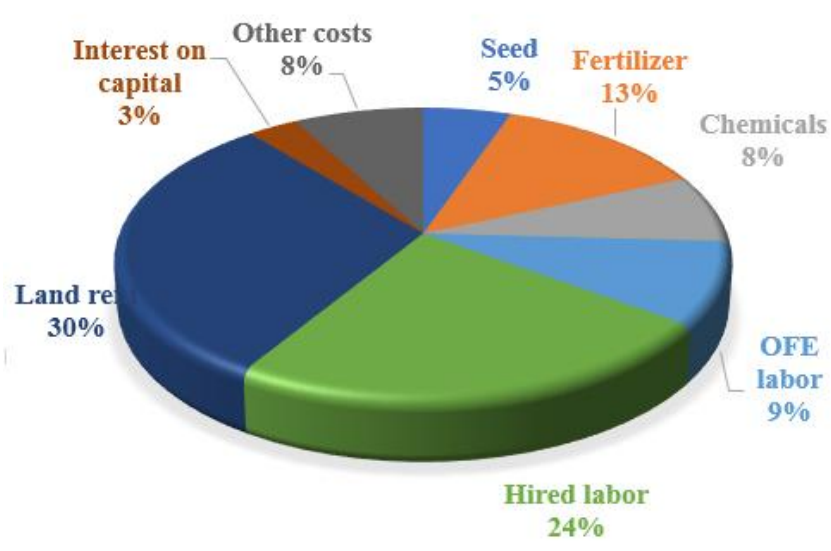

Oriental Mindoro

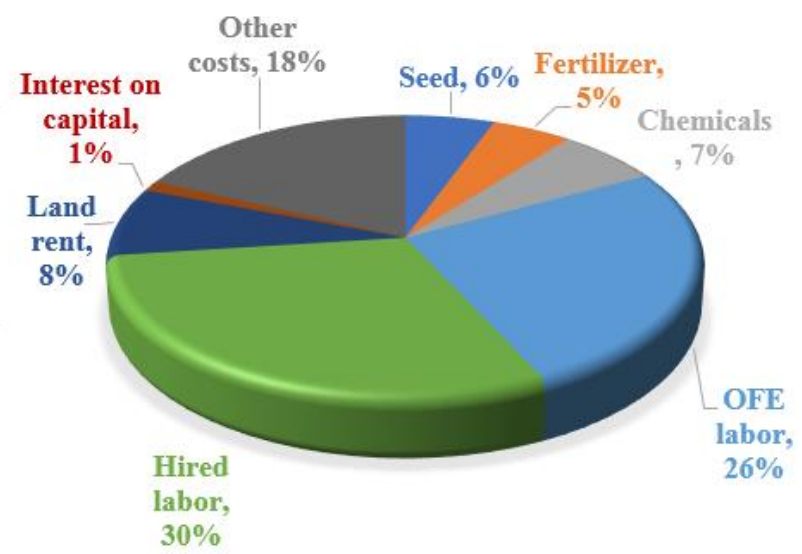

Apayao

Figure-2. Cost shares (\%) in aromatic rice production, 2017.

Table-4. Costs and returns of aromatic rice production, 2017.

\begin{tabular}{|c|c|c|}
\hline \multirow{2}{*}{ Items } & Oriental Mindoro & Apayao \\
\hline & $\mathrm{n}=42$ & $n=40$ \\
\hline \multicolumn{3}{|l|}{ Returns } \\
\hline Yield $\left(\mathrm{kg} \mathrm{ha}^{-1}\right)$ & 4,754 & 2,016 \\
\hline Paddy price (peso $\left.\mathrm{kg}^{-1}\right)$ & 19 & 18 \\
\hline Gross revenue (peso ha-1) & 92,397 & 36,145 \\
\hline \multicolumn{3}{|l|}{ Costs $($ peso ha-1) } \\
\hline Seed & 3,340 & 1,403 \\
\hline Fertilizer & 8,199 & 1,260 \\
\hline Chemicals & 4,693 & 1,639 \\
\hline Non-chemical materials & 15 & 2 \\
\hline Hired labor & 14,931 & 7,541 \\
\hline Operator, family, \& exchange (OFE) labor & 5,810 & 6,556 \\
\hline Land rent & 19,039 & 1,983 \\
\hline Interest on capital & 1,918 & 290 \\
\hline Other costs* & 4,957 & 4,536 \\
\hline Total paid-out cost (peso ha-1) & 44,173 & 16,580 \\
\hline Total cost $\left(\right.$ peso ha $\left.{ }^{-1}\right)$ & 62,901 & 25,211 \\
\hline Cost per unit (peso $\left.\mathrm{kg}^{-1}\right)$ & 13 & 13 \\
\hline Net income from rice farming $($ peso ha-1) & 29,495 & 10,934 \\
\hline Net returns over paid-out costs (peso ha $\left.{ }^{-1}\right)$ & 48,224 & 19,566 \\
\hline
\end{tabular}

\subsection{Supply and Demand Estimates}

Figure 3 shows the estimated supply and demand of aromatic rice side-by-side. Among all SR types, aromatic rice comprises the largest volume of production since it is the most comparable to ordinary white rice. It accounts for $73 \%$ of the total SR area harvested. Using the average yield of $3.14 \mathrm{t} \mathrm{ha}^{-1}(14 \% \mathrm{MC})$ and the estimated area of 345,000 ha, the estimated local production is 671,000 tons. With an import volume of $12,500 \mathrm{t}$ year-1, the total supply is about 683,500 tons, majority of which comes from MIMAROPA (Region 4B). Traditional rice varieties planted in upland areas (e.g., Apayao) once a year also contribute to the totality. The country mostly imports aromatic rice from Thailand.

For the estimation of demand, the study assumed that those belonging to the upper-middle-to-rich population (25\%) are more likely to purchase aromatic rice. With an average per capita consumption of $87 \mathrm{~kg}^{\mathrm{year}}{ }^{-1}$ (Mataia et al., 2020) this translates to an annual food demand of roughly 600,000 t. Adding the yearly seed requirement of 
about $75 \mathrm{~kg} \mathrm{ha}^{-1}$ or a total of 17,000 $\mathrm{t}$ in milled rice equivalent, total estimated demand is around $617,000 \mathrm{t}$ year ${ }^{-1}$. This shows that local supply with minimal imports meets the domestic demand for aromatic rice. Aromatic rice is usually sought in highly urbanized areas such as Metro Manila and CALABARZON (Region 4A), and some parts of Central Luzon (e.g., Bulacan and Pampanga). Potential demand areas in the south are the cities of Cebu and Davao.

700,000

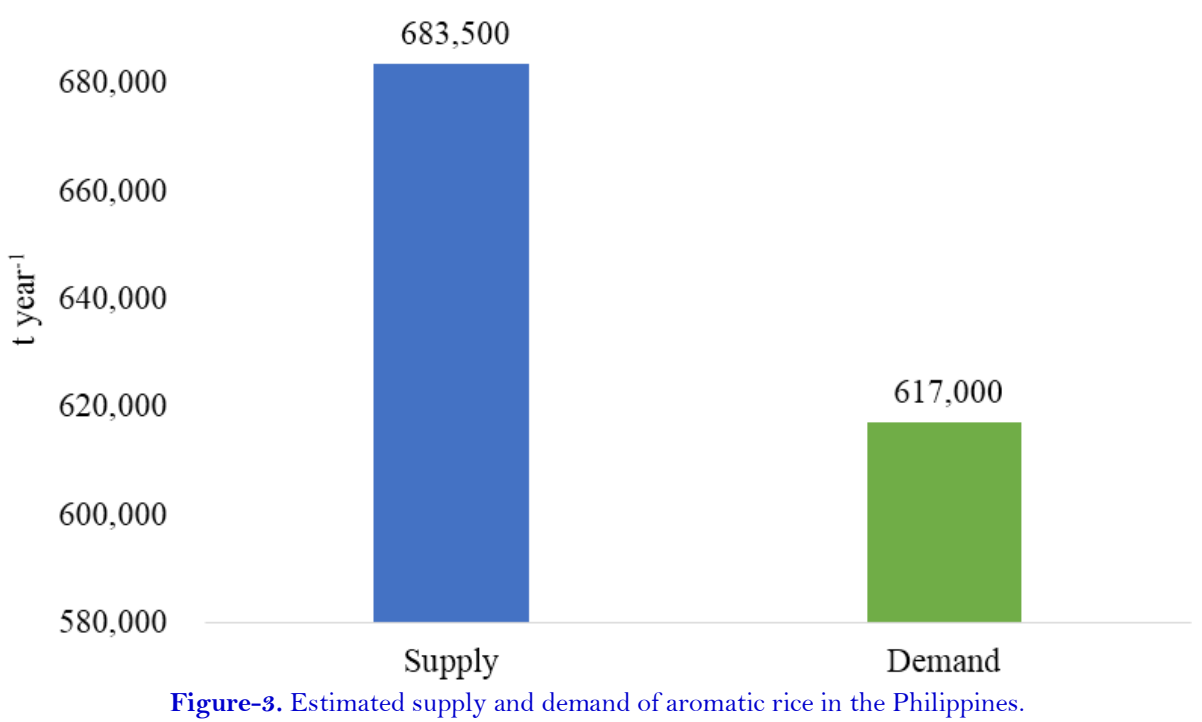

\section{CONCLUSION}

The profiles of aromatic rice farmers in both provinces were comparable in terms of age, educational attainment, and farming experience. Notable difference was observed in the men-to-women ratio as Apayao growers were more female-dominant. The gender differentiation reported in farming activities should be considered in crafting training designs and implementing extension interventions for the aromatic rice producers. Another significant finding was the substantial percentage of Apayao farmers who were non-members of any rice-based organization. This imposes an adverse impact on farmers' access to government support such as technical assistance, provision of credit, and machinery.

Productivity of aromatic rice in Oriental Mindoro was comparable with the national average, but there is room for yield enhancement and cost reduction. First, supply of seeds must be ensured to maintain the quality and sustain cultivation, especially in the case of NSIC Rc 218. PhilRice stations near existing and potential production areas should particularly propagate and commercialize these seeds. Additionally, newly released aromatic varieties that mimic NSIC Re 218 should be introduced and made available in the area. It should be noted that a stringent system for truthful labeling must be in place since there were reports on NSIC Rc 218 being marketed as Dinorado. Moreover, the National Rice Program (NRP) and the Rice Competitiveness Enhancement Fund (RCEF)-Seed Program can produce certified seeds of this variety to be available in identified regions concentrating on aromatic rice production such as MIMAROPA. Rice research and breeding should be conducted in support of these ventures. Second, the adoption of integrated pest management should be intensified in the province, given their heavy use of pesticides as primary response to pest and disease infestations. Lastly, land conversion policies should be strictly implemented to lessen the cost of land rent. Urbanization and land conversion in the province resulted in high cost of land rent. This modernization thrust is expected to escalate through the years and the value of aromatic rice must accord with this to ensure sustainability.

Traditional aromatic rice varieties (e.g., Dinorado) in Apayao are typically cultivated in the upland ecosystem with low use of fertilizers and pesticides. These conditions caused lower yields compared with lowland and modern rice varieties. Hence, aromatic rice production in the province is more considered as subsistence farming. Despite 
this situation, productivity can still be improved and costs can be reduced. This study reinforces the recommendations for upland rice farming given by the Heirloom Rice Project. First, availability and access to pure seeds must be safeguarded through community seed banking (CSB). Such seed banks are the repository of local seeds that facilitates exchange among community members (Vernooy, Sthapit, \& Bessette, 2017). In support of this, training on seed purification must be conducted and CSB infrastructures must be developed. Second, PalayCheck for Highland Rice Production System and Diversified Farming Technologies must be introduced to the aromatic rice farmers. This module contains recommended farming techniques and strategies to improve productivity and profitability. For varietal selection, smaller bundles of panicles are recommended to achieve uniform drying of grains. Proper storage must also be done to prolong shelf-life and ensure good germination. For land preparation, microtillers are recommended for soil tillage for flat to slightly rolling fields in order to reduce manual labor cost. Further details of technology recommendations for upland rice farming are discussed in PalayCheck for Highland Rice Production System and Diversified Farming Technologies (Miranda, 2017).

On grain quality, aroma is clearly the most important attribute. After series of evaluation, Gobyerno and Azucena from Apayao and NSIC Rc 218 from Oriental Mindoro were identified as the top local aromatic rice varieties due to their evident pandan-like scent, good taste, and tenderness when cooked. Proper postharvest practices must be observed to maintain these unique and premium qualities. First, sun drying, if weather permits, is recommended to achieve the desired MC level. It is recommended to set a maximum thickness of paddy layer at 4 inches and stirring every 30 minutes. Mechanical dryers that use biomass or petroleum are not recommended as this produces a smoky odor that could neutralize the pandan-like scent. Electric mechanical dryers may be used instead, if available, as a shared facility in a community, to accommodate bigger volume and reduce cost. Second, favorable levels of temperature and humidity must be secured in storing these rice types to maintain the recommended $\mathrm{MC}$ of $12-14 \%$ and more importantly, the aroma. This SR type must be stored in paddy form for a shorter period than ordinary rice.

As aromatic rice is being positioned in the market, it is important to widen the demand and still offer an affordable price. Blending of aromatic rice with ordinary white rice is recommended to cater to specific preferences of consumers. The optimum mixture should be reinforced with truthful labeling for transparency on rice quality. PhilRice, through its Rice Chemistry and Food Science Division (RCFSD), can assist in determining this optimum blend. Developing marketing strategies and creating linkages will also boost the demand for SR.

This study concludes that the current local aromatic rice industry has opportunities for import substitution. Local farmers must be empowered to increase local production as response to the increasing demand for aromatic rice and to the ramifications of RTL.

Funding: This research is funded by the Department of Agriculture - Bureau of Agricultural Research, Diliman, Quezon City, Philippines.

Competing Interests: The authors declare that they have no competing interests.

Acknowledgement: All authors contributed equally to the conception and design of the study.

\section{REFERENCES}

Anies, A. J. P., Corpuz, H. M., \& Romero, M. V. (2014). Traditional upland rice varieties in Mindanao [Phillippines] with excellent quality and high antioxidant properties. Philippine Journal of Crop Science (Philippines).

Ashfaq, M., Haider, M. S., Saleem, I., Ali, M., Ali, A., \& Chohan, S. A. (2015). Basmati rice-a class apart (a review). Journal of Rice Research, 3, 156. Available at: https://doi.org/10.4172/2375-4338.1000156.

Bairagi, S., Demont, M., Custodio, M. C., \& Ynion, J. (2020). What drives consumer demand for rice fragrance? Evidence from South and Southeast Asia. British Food Journal, 122(11), 3473-3498. Available at: https://doi.org/10.1108/BFJ-012019-0025. 
Beltran, J. C., Bordey, F. H., Launio, C. C., Litonjua, A. C., Manalili, R. G., Mataia, A. B., \& Moya, P. F. (2016). Rice prices and marketing margins. In: Bordey, F.H., Moya, P.F., Beltran, J.C., \& Dawe, D.C. (Eds.), Competitiveness of Philippine rice in Asia (pp. 129-140). Science City of Munoz (Philippines): Philippine Rice Research Institute and Manila (Philippines): IRRI.

Beltran, J. C., Romero, M. V., Relado-Sevilla, R. Z., Bordey, F. H., \& Moya, P. F. (2020). The specialty rice data: Sources, concepts, and methods. In: Beltran, J.C., Bordey, F.H., Moya, P.F., Relado-Sevilla, R.Z., \& Romero, M.V. (Eds.), Philippine specialty rice: Understanding production, culture, quality, and market (pp. 11-22.). Science City of Muñoz, Nueva Ecija (Philippines): Philippine Rice Research Institute and Manila (Philippines): International Rice Research Institute.

Buttery, R. G., \& Ling, L. C. (1982). 2-Acetyl-1-pyrroline: An important aroma component of cooked rice. Chemistry \& Industry, 1982(1982), 958-969.

Calingacion, M., Laborte, A., Nelson, A., Resurreccion, A., Concepcion, J. C., Daygon, V. D., \& Bassinello, P. Z. (2014). Diversity of global rice markets and the science required for consumer-targeted rice breeding. PloS One, 9(1), e85106.

Chaudhary, R. C., Van Tran, D., \& Duffy, R. (2001). Specialty rices of the world: Breeding, production, and marketing. Rome (Italy): Science Publishers, Inc.: Food and Agriculture Organization of the United Nations.

DA (Department of Agriculture). (2015). Value chain analysis and competitiveness strategy: Aromatic and pigmented rice Luzon a cluster. Manila (Philippines): Philippine Rural Development Project (PRDP) I-Plan Component Luzon A Cluster.

De Leon, J. C. (2012). Rice that Filipinos grow and eat. Philippine Institute for Development Studies. Research Paper Series No. 2011-01.

De Leon, J., Del Rosario, C., Arocena, E., \& Yoshihashi, T. (2004). Re-discovery of several aromatic traditional rice (Oryza sativa L.) varieties of the Philippines. Philippine Journal of Crop Science (Philippines).

Dela Cruz, M., Galindez, J., \& Tapic, R. (2017). Productivity and grain quality of aromatic rice lines under organic cultivation. Philippine Journal of Crop Science (Philippines).

Ehiakpor, D. S., Apumbora, J., Danso-Abeam, G., \& Adzawla, W. (2017). Households' preference for local rice in the Upper East Region, Ghana. Hindawi Advances in Agriculture, 1-9. Available at: https://doi.org/10.1155/2017/1812975.

Gaur, A., Shabir, W. H., Pandita, D., Bharti, N., \& Malav, A. (2016). Understanding the fragrance in rice. Journal of Rice Research, 4(1), e125. Available at: https://doi.org/10.4172/2375-4338.1000e125.

Giraud, G. (2008). The world market of fragrant rice, main issues and perspectives. International Food and Agribusiness Management Review, 16(2), 1-20.

Mataia, A. B., Romero, M. V., Bandonill, E. H., Mamucod, H. F., Ante, R. H. L., Beltran, J. C., \& Bordey, F. H. (2020). Consumer and institutional preferences. In: Beltran, J.C., Bordey, F.H., Moya, P.F., Relado-Sevilla, R.Z., \& Romero, M.V. (Eds.), Philippine specialty rice: Understanding production, culture, quality, and market (pp. 89-108). Science City of Muñoz, Nueva Ecija (Philippines): Philippine Rice Research Institute and Manila (Philippines): International Rice Research Institute.

Mbanjo, E. G. N., Jones, H., Caguiat, X. G. I., Carandang, S., Ignacio, J. C., Ferrer, M. C., \& Kretzschmar, T. (2019). Exploring the genetic diversity within traditional Philippine pigmented Rice. Rice, 12(1), 1-18. Available at: https://doi.org/10.1186/s12284-019-0281-2.

Miranda, R. B. (2017). Completion report: Raising productivity and enhancing the legacy of heirloom/traditional rice through empowering communities in unfavorable rice-based ecosystem. Heirloom Rice Project. Nueva Ecija (Philippines): Philippine Rice Research Institute.

Oad, G. L., Oad, F. C., Bhand, A. A., \& Siddiqui, M. H. (2006). Performance of aromatic rice strains for growth and yield potentials. Asian Journal of Plant Sciences, 5(3), 531-533. Available at: https://doi.org/10.3923/ajps.2006.531.533.

Official Gazette of the Republic of the Philippines. (1997). Republic Act No. 8371 . Retrieved from https://www.officialgazette.gov.ph/1997/10/29/republic-act-no-8371. 
PhilRice (Philippine Rice Research Institute). (2012). Rice-based farm household survey round dry season 2012: Labor requirements (person-days/ha), by cropping season. Nueva Ecija (Philippines): PhilRice.

PhilRice (Philippine Rice Research Institute). (2018). Suitable rice varieties for every region named. Retrieved from https://www.philrice.gov.ph/suitable-rice-varietiesevery-region-named/.

Ponleu, C., \& Sola, H. (2018). Overview of the Cambodian rice market: Challenge and the way forward. Thailand: Kasetsart University.

Prasad, G. S. V., Padmavathi, G., \& Suneetha, K. (2020). Assessment of diversity of Indian aromatic rice germplasm collections for morphological, agronomical, quality traits and molecular characters to identify a core set for crop improvement. CABI Agriculture and Bioscience, 1(13), 1-24. Available at: https://doi.org/10.1186/s43170-020-00013-8.

Prodhan, Z. H., \& Qingyao, S. (2020). Rice aroma: A natural gift comes with price and the way forward. Rice Science, 27(2), 86100. Available at: https://doi.org/10.1016/j.rsci.2020.01.001.

Romero, M. V., Mamucod, H. F., Bandonill, E. H., Corpuz, G. A., Belgica, P. R., Huliganga, R. C., \& Bordey, F. H. (2020). Grain quality and health-promoting properties. In: Beltran, J.C., Bordey, F.H., Moya, P.F., Relado-Sevilla, R.Z., \& Romero, M.V. (Eds.), Philippine specialty rice: Understanding production, culture, quality, and market (pp. 135-182). Science City of Muñoz, Nueva Ecija (Philippines): Philippine Rice Research Institute and Manila (Philippines): International Rice Research Institute.

Roy, S., Banerjee, A., Basak, N., Kumar, J., \& Mandal, N. P. (2020). Aromatic rice. In: Costa de Oliveira A, Pegoraro C, Ebeling Viana V. (Eds.), The Future of Rice Demand: Quality Beyond Productivity. Cham: Springer.

Thang, T. (2017). Current status of Vietnam rice export quality. Taipei: FFTC Agricultural Policy Platform.

United Nations. (1995). The rice economy: Market structure and prospects (pp. 43). Geneva (Switzerland): United Nations.

Vanavichit, A., Kamolsukyeunyong, W., Siangliw, M., Siangliw, J. L., Traprab, S., Ruengphayak, S., \& Toojinda, T. (2018). Thai Hom Mali Rice: Origin and breeding for subsistence rainfed lowland rice system. Rice, 11(1), 1-12. Available at: https://doi.org/10.1186/s12284-018-02 12-7.

Vernooy, R., Sthapit, B., \& Bessette, G. (2017). Community seed banks: Concept and practice - facilitator handbook. Rome (Italy): Biodiversity International.

Widjaja, R., Craske, J. D., \& Wootton, M. (1996). Comparative studies on volatile components of non-fragrant and fragrant rices. Journal of the Science of Food and Agriculture, 7O(2), 151-161. Available at: https://doi.org/10.1002/(sici)10970010(199602)70:2\%3C151::aid-jsfa478\%3E3.0.co;2-u.

Views and opinions expressed in this article are the views and opinions of the author(s), International Journal of Sustainable Agricultural Research shall not be responsible or answerable for any loss, damage or liability etc. caused in relation to/arising out of the use of the content. 